\title{
ALTERNATIVES AND RESPONSIBILITY: AN ASYMMETRICAL APPROACH*
}

Carlos J. Moya, University of Valencia (carlos.moya@uv.es)

Abstract: In this paper, I defend an asymmetrical view concerning the relationship between alternative possibilities and moral responsibility, according to which alternative possibilities are required for being blameworthy, but not praiseworthy, for what one decides or does. I defend the non-necessity of alternatives for praiseworthiness through an examination of what I call 'Luther' examples. My defence of the necessity of alternatives for blameworthiness proceeds instead through an analysis of so-called 'Frankfurt' examples. In both cases, my arguments rest on the contention that, in ascriptions of moral responsibility, the primary question is not whether the agent could have done otherwise, but whether she should have done what she did, so that the former question only becomes pressing when the answer to the latter is negative. Concerning moral responsibility, then, the concept of moral obligation or duty is prior to that of alternative possibilities.

\section{Introduction: moral responsibility, alternatives and moral obligation}

The Principle of Alternative Possibilities (PAP) can be stated thus: "A person is morally responsible for something she has done only if she was able to do otherwise". For the last forty years or so this principle has been the object of a long and intricate discussion. Philosophically speaking, the really important question is not PAP itself, but the core intuition behind it, namely, that alternative possibilities (APs) are necessary for moral responsibility (MR). In what follows, with "PAP" I shall refer to this core intuition. According to some thinkers (Harry Frankfurt 1969, John Fischer 1994, Derk Pereboom 2001, 2009...) PAP is false. Others contend that it is true (Margery Naylor 1984, Keith Wyma 1997, Michael Otsuka 1998...). These are the two main positions about this important issue. There are, however, a minority of philosophers (Susan Wolf 1990, Dana Nelkin 2008...) who hold an asymmetrical view according to which PAP is true for blameworthy actions, but false for praiseworthy ones. In other words, APs are

\footnotetext{
* With my warmest congratulations to Kevin Mulligan, in acknowledgment of a long and fruitful career devoted to philosophical research and teaching.
} 
required for negative MR (blameworthiness, reprehensibility), but not for positive MR (praiseworthiness, laudability). In this paper, and unlike what I used to hold, I will side with this minority position and defend an asymmetrical view of this kind.

Susan Wolf's defence of asymmetry is based on a theoretical approach to MR which she labels the "Reason View" according to which, in her own words, "an individual is responsible if and only if she is able to form her actions on the basis of her values and she is able to form her values on the basis of what is True and Good" (Wolf 1990, p. 75). In everyday terms, what is necessary and sufficient for MR is to be able to distinguish between good and evil and to act on the basis of the former. Now, asymmetry follows from this account. If a person behaves rightly and on the basis of correct values, this shows that she has the required ability, and so is responsible for what she did, no matter whether she could have behaved in a different and less admirable manner. Instead, if a person does a wrong thing or does a right thing but on the basis of wrong or distorted values, it is not clear whether she has the required ability and so whether she is morally responsible. For her to be so, she must be able to act in a morally right way on the basis of correct values: she must be able to do otherwise. APs are, then, required in order to be blameworthy, but not praiseworthy, for what one does. In a recent paper, and following Wolf's steps, Dana Nelkin defends a similar asymmetrical view, which she labels "the rational abilities view":

I defend a view according to which one is responsible for one's actions to the extent that one has the ability to do the right thing for the right reasons. This view is asymmetrical in requiring the ability to do otherwise when one acts badly or for bad reasons, but no such ability in cases in which one acts well for good ones" (Nelkin 2008, p. 497).

Though not unrelated to Wolf's and Nelkin's, my own defence of an asymmetrical view concerning APs rests instead on the concept of moral obligation or moral duty. This is a central notion in our everyday conception of MR. More generally, the idea of obligation, of what one should or should not do in certain contexts and circumstances, is a crucial element in social life and social interaction. We all have strong expectations about how others (and ourselves) should behave, and react in negative ways when these expectations are frustrated. Social roles and their effective playing are central ingredients of human society. Following a relatively old trend in 
sociology called "symbolic interactionism", a role can be conceived as a set of mutual expectations, which involve certain obligations and, eventually, sanctions. Social institutions, in turn, would amount to organized sets of such roles. Moral expectations, moral obligations and moral sanctions are a partial aspect of this general social frame; they are an integral part of the institution of morality, with ascriptions of MR, of praise and blame, as a central aspect of it. So, far from being trivial or unimportant, the concept of moral obligation has a principal place in human life.

Now, my proposal is that we can best understand the place of the demand for APs in ascriptions of MR by going through the concept of moral obligation, of what people should or should not do or have done.

In our folk conceptual frame, I contend, MR is related to APs, to freedom to do otherwise, through the mediating notion of moral obligation. In assessing MR in particular cases, our primary concern is not whether the agent could have done otherwise, but whether she should or should not have done what she did. And, as I will argue, the question whether the agent could have done otherwise is normally raised only when we judge that the agent should not have acted as she did. Instead, when an agent has behaved as she should, and for the right reasons, there is nothing that she should have done and did not do; this being so, there is usually no point in asking whether she could have done what she should not have done. Maybe she could; but even if she could not, this does not detract from her praiseworthiness; on the contrary, it may make her more praiseworthy than she would have been if she could have done otherwise. As Wolf has pointed out, if a person who sees someone else in danger of drowning considers seriously the possibility of not jumping in the water owing to, e.g., possible damage to her garments, we will probably consider her as less praiseworthy than another who simply does not hesitate at all in jumping in the water and does not even consider the possibility of doing otherwise. Consider also Luther's statement, when urged to retract his religious views and stop his challenge to the Roman Church: "Here I stand; I can do no other". In my 2006 book, I labelled cases of this kind, in which a person sees so clearly what her duty is that it is unthinkable for her to act in a different way, 'Luther' cases. Cases of this sort have often been used to show the falsity of PAP. They play a central role in Dennett's rejection of this principle (cf. Dennett 1984, p. 133). Dennett uses in fact Luther's example, and he presents as well, as a case of this sort, his conviction that he himself would be unable to torture an innocent person for one thousand dollars. These cases also play an important role in Harry Frankfurt's work on 
MR; he considers some boundaries of a person's will, which he calls volitional necessities, as an integral part of that person's freedom and autonomy and a central root of MR, in opposition to a view that insists almost exclusively on the importance of choice among APs.

As is well known, and unlike Dennett, Frankfurt does not base his rejection of PAP on 'Luther' cases, but mainly on cases which he himself designed and which, because of it, have come to be known as Frankfurt (or Frankfurt-style) cases. To anticipate, these are cases in which, putatively, an agent is morally responsible for what she has done though, unknown to her, she could not have done otherwise. However, in spite of these differences, it is pretty clear that both Dennett and Frankfurt take the respective cases to refute PAP concerning MR in general, that is, both as praise- and as blameworthiness. This is obvious in Dennett's case, but it is also pretty clear in Frankfurt's. ${ }^{1}$ However, in both kinds of cases we can find interesting asymmetries, related to moral obligation and the moral quality of the action.

\section{'Luther' cases}

Let us attend to 'Luther' cases first. As Dennett himself rightly points out, we do not find Luther's avowal, “I can do no other", as a sign of fragility of his rational faculties, but rather as a manifestation of their strength and soundness. And this is so even if, owing to the firmness of his convictions and values, he is actually psychologically unable to retract his religious and political stance. Concerning our moral assessment, we tend to see his avowal and the strength of his commitment as a sign of moral integrity; his inability to recant does not undermine his praiseworthiness; it rather increases it. Luther acted as he should. There is not a different way of acting that he should have gone for. So, even if he actually could have behaved differently, this is either irrelevant to his moral praiseworthiness or even damaging to it. Reflection on cases of this kind makes us aware that we do not demand APs in order for an agent to be praiseworthy for a morally good or admirable action. More common are examples of volitional necessities, to use Frankfurt's terms. Dennett's inability to torture an innocent person for one thousand dollars is an example. But all of us can think of many others. For

\footnotetext{
${ }^{1}$ So, after presenting his putative counterexample to PAP, Frankfurt writes: "It would be quite unreasonable to excuse Jones4 for his action, or to withhold the praise to which it would normally entitle him, on the basis of the fact that he could not have done otherwise" (Frankfurt 1969, p. 7, my emphasis).
} 
instance, as I presently am, I simply would be unable, not only to harm my daughters, but even to want to harm them. This is simply unthinkable for me. But I do not see why this deprives me of the praise I deserve, if I actually do, for caring about them and being a decently good father.

Things are very different, however, when someone acts in a morally wrong and objectionable way. Suppose that someone deliberately shows a vile and appalling attitude towards a weak and poor person, insulting or even beating her. Now imagine that the aggressor utters the same words as Luther did: "I can do no other". In this case, unlike Luther's, we do not take naturally this avowal as a manifestation of the soundness and good functioning of the aggressor's rational faculties. Rather, we tend to assume that something is wrong with her, either in her rationality or in her moral sense, or both. And even if she adopts this attitude towards poor people as a result of her sincere belief in, say, a strong form of social Darwinism, we still do not tend to see her avowal, unlike Luther's, as a sign of her moral integrity, but rather as a symptom of her moral impairment or depravation. In this case, unlike Luther's, we assume that there is a different way of acting that she should have gone for; and we also assume that there is a different way of seeing things and of reasoning that she should have adopted. And, lacking evidence to the contrary, we assume that, since she should have had different beliefs and acted in a different way, she could have done so. Given that she should, and could, have done otherwise but did not, she is so far morally blameworthy. We assume, then, that APs are relevant, in fact required, for moral blameworthiness as unfulfilled moral obligations that the agent was able to fulfil. This is why APs are not required in cases of morally praiseworthy acts: here there are no unfulfilled duties, and so no alternative ways of behaving, in which the agent satisfies them, are necessary for the agent to be blameless or praiseworthy. This is not so with blameworthy actions. So, Dennett was wrong in concluding, from the fact that APs are not required for an agent's MR in 'Luther', praiseworthiness cases, that PAP is false in all cases.

We have contended that, in the context of MR ascriptions, when we hold that an agent should have acted in a different way than she did, we naturally assume that she could have acted in that way. This assumption is an application of an old moral principle, namely, that 'ought' implies 'can' (OIC). This principle seems to me fully reasonable; its plausibility stands out especially in its contrapositive form: if someone is unable to $\mathrm{A}$, then she is not morally obliged to A. If someone cannot swim, she is not morally obliged to jump in the water in order to save a drowning person. The general 
moral duty to help someone in danger of dying gets suspended in this particular context and for this particular person precisely because she was unable to fulfil it. As I wrote some years ago, "Denying it [OIC] means to find it acceptable to burden people with moral duties that they cannot discharge, and to hold them morally responsible for actions that it is not in their power not to perform. Too much moral weight to carry, it seems" (Moya 2006, p. 30). This principle is under some pressure nowadays, and part of the reason some people have for rejecting it is precisely their rejection of PAP. But it is not clear at all that PAP is false, at least concerning blameworthiness.

Some people take moral dilemmas to be counterexamples to OIC; the reason is that, in them, supposedly, people ought to do something despite being unable to do it. But I think this is not right. Consider Sartre's example of the young Frenchman who faces the dilemma between joining the Résistance against the Nazis or taking care of his elderly and ill mother. This dilemma does not refute OIC, in my view. The agent has a moral duty to join the Résistance; but he can fulfil this duty by joining the Résistance, as OIC states. On the other hand, he has a moral duty to take care of his mother; but he can fulfil this duty by taking care of his mother, again as OIC says. But I think he has not the moral duty to do both, that is, to join the Résistance and to take care of his mother simultaneously, precisely because doing that is impossible for him, as looks pretty correct and OIC implies. In general, "S ought to A" and "S ought to B" do not logically imply "S ought to both A and B". Rather than seeing the falsity of PAP as a reason for rejecting OIC, my advice is to see the truth of OIC as a reason for accepting PAP as well.

Now, in the context of our proposal, we can explain a fact that has intrigued me for some years, namely that PAP can be derived from OIC in the case of moral blameworthiness, but not of moral praiseworthiness. In the former case, the derivation can proceed thus:

A person is morally blameworthy for A-ing only if she ought not to have A-ed (Premise P)

A person ought not to have A-ed only if she was able not to A (OIC)

Therefore,

A person is morally blameworthy for A-ing only if she was able not to A (PAP, applied to blameworthiness, by transitivity of the implication) 
The first premise asserts, plausibly enough, that blameworthiness implies a violation of a moral duty: the agent did something she should not have done (or omitted to do something she should have done). The second premise is OIC.

Let us try now the derivation of PAP from OIC in the case of praiseworthiness:

A person is morally praiseworthy for A-ing only if she ought to have A-ed (Premise P')

A person ought to have A-ed only if she was able to A (OIC)

Therefore,

A person is morally praiseworthy for A-ing only if she was able to A.

The conclusion in this case may be interesting: it suggests that A-ing by mere luck, even if A-ing is morally right, does not make someone praiseworthy. Interesting as this may be, it is not what PAP says, however.

These logical relations are illuminating of internal conceptual connections in the field of MR. PAP connects blameworthiness for A-ing (not A-ing) with ability not to A (to A); the relation may not be obvious, and it actually has been strongly contested; OIC connects moral obligation (not) to A with ability (not) to A; and Premise P provides the missing link by connecting blameworthiness for (not) A-ing with moral obligation not to A (to A). OIC and Premise P provide the rationale for PAP, by justifying the connection it establishes between avoidability and blameworthiness. And they also show why PAP cannot be derived from OIC for praiseworthy actions: Premise P is not true when we substitute "praiseworthy" for "blameworthy"; it is not true that an agent is praiseworthy for A only if she ought not to have A-ed; but this transit from A to not-A, which Premise P makes, is essential for PAP to be derived, since it also contains this relation. Praiseworthy actions, however, confirm OIC: since the agent has done what she should, she clearly was able to do it.

\section{Frankfurt cases}

Let us now attend to Frankfurt cases. They are probably the most important reason why many thinkers have been led to think that PAP is false (and to reject OIC as well). A typical Frankfurt case might be the following. 
(ANN) Ann, a student, hates her colleague John and decides to lie to him about the date of an oncoming examination. As a result, John misses the exam, with some nasty consequences for him. Unbeknownst to Ann, Black, a clever and nefarious neurosurgeon who also wants Ann to lie to John, has implanted in her brain a device that allows him to monitor Ann's deliberation. If, on this basis, it is clear to Black that Ann is going to decide not to lie, he will press a button that will ensure that Ann will decide to lie. However, Black prefers not to intervene unless it is necessary. And it is not, for Ann, deliberating fully on her own and for her own reasons, decides to lie to John and Black never presses his button.

This example raises a strong intuition to the effect that Ann is fully morally blameworthy for lying to John even if, owing to the lurking presence of Black, she could not have avoided lying. If so, then PAP is false. A way of resisting this conclusion is to hold that some APs remain. Ann could, for example, have shown the sign that would have alerted Black of an oncoming decision to tell the truth instead of lying. Or she could have postponed her lie. However, not any AP goes in order to sustain PAP against Frankfurt cases. To use Fischer's terms, APs have to be robust in the sense of being explanatorily relevant to an agent's MR. Exactly what robustness or explanatory relevance includes is a matter of some controversy, but two aspects seem to be essential to it. ${ }^{2}$ First, in order to be robust, an alternative has to be under the agent's control. Suppose that Ann might have accidentally fainted before lying to John. It looks clearly wrong to try to save PAP by adverting to this alternative, even if it is present. Moreover, a robust alternative possibility has to be morally significant, in the sense that its presence is relevant to the question of whether the agent is morally responsible. So, for instance, though it was within Ann's control to lie to John in a lower or higher tone of voice than she actually used, this alternative is not relevant to her blameworthiness for lying. Some thinkers, such as Pereboom or Otsuka insist on a third and very strong requirement, namely that robust APs have to be such that, had the agent gone for them, she would have been fully exempted from blameworthiness. Though quite demanding, the requirement has some plausibility. ${ }^{3}$ In this paper, I will accept this third requirement, at least for the sake of the argument.

\footnotetext{
${ }^{2}$ A good and useful characterization can be found in Capes 2010, esp. pp. 69-70.

${ }^{3}$ Pereboom may be right that the intuition behind the requirement of APs for MR is the "off the hook" intuition, the assumption that, in order to be blameworthy for some
} 
Now, in the context of our proposal, when we explain an agent's blameworthiness by appealing to things she could have done but did not, we are presupposing that these are things that she should have done but did not. In our view, then, robust, morally significant APs are unfulfilled moral duties. Irrelevant APs, mere "flickers", to use Fischer's term again, are so because they are not things that the agent should have done to be exempted from blame. Our example of Ann's lying in a lower or higher tone of voice is a case at hand. Our account can give, then, a principled justification of the requirement of robustness and moral significance for those APs that, in Frankfurt cases, can be adverted to in order to defend PAP.

The intuitions raised by Frankfurt cases may be explained thus: if a rational and reasons-responsive agent deliberated, decided and acted fully on her own and for her own reasons, without being coerced or compelled, she is morally responsible for what she did; it does not matter for her MR whether, unbeknownst to her, there are factors in the situation that, without interfering at all in the process of decision and action, make it impossible for her to decide and act otherwise. So, why should we accept that someone is morally responsible for something she did only if she could have done otherwise? The supposedly obvious connection between MR and APs begins to appear as rather arbitrary and groundless.

Things look different, however, if, following our proposal, we introduce the concept of moral obligation. Instead of asking, in a situation where MR is at issue, whether the agent could have done otherwise, let us start by asking whether the agent should have done otherwise. This question has an immediate and direct impact on the agent's MR. If the answer is affirmative, so that the agent did not act as she should, then there is prima facie reason to think that she is blameworthy for what she did. Now, whereas saying, "She is morally blameworthy for what she did because she could have done otherwise" may be in need of further justification, saying, "She is morally blameworthy for what she did because she should have done otherwise" is not. In fact, it could be used as part of a justification of the former statement, for, if we hold that someone should have done other than she did, we are assuming, applying OIC, that she was able to do it.

action, one must be able to act in a way that makes one fully blameless. This is essentially Otsuka's Principle of the Avoidability of Blame (cf. Otsuka 1998), a principle that he thinks respects the spirit of PAP and is not refuted by Frankfurt cases, even if PAP itself might be 
When it is praiseworthiness that concerns us, things change significantly. Saying, "She is morally praiseworthy for what she did because she could have done otherwise" is not simply in need of further justification; it looks rather dubious, if not false, in view of 'Luther' cases. The corresponding "should" statement would be, "She is morally praiseworthy for what she did because she did what she should"; and clearly, if we say this, we are not assuming that she could have done otherwise (even if she actually could). So, unlike blameworthiness, here we cannot use the "should" statement to justify the "could" statement.

How does all this affect Frankfurt cases? Concerning them, a primary question would be, "Did the agent do what she should, morally speaking?" If the answer is positive, then, ceteris paribus, the agent is morally praiseworthy, and the question, "Could she have done otherwise?" does not change this positive assessment.

Suppose, however, that the answer to that primary question is negative; then there seem to be unfulfilled moral duties, things that the agent should have done but did not. In such a case, the question whether she could (was able to) have done those things becomes crucial. If she could, then she had within her reach robust, even exempting, APs, unfulfilled moral duties such that, had she fulfilled them, her blame would have decreased or even disappeared. Suppose, however, that the agent could not have done the things she should have done. In this case, given OIC, there were no unfulfilled moral duties after all, for on this occasion they were suspended for the agent by virtue of her impossibility to satisfy them. But then she is not blameworthy, for there was nothing that she should have done but did not.

In either case, then, PAP, applied to blameworthiness, is confirmed. In the first case, in which the agent could have fulfilled her duties, she is blameworthy, but she had robust, even exempting, APs. In the second case, she had no robust APs, but she was not blameworthy, either.

Frankfurt theorists will object to the preceding considerations on the following lines. Assuming the truth of OIC is sort of question begging against them, for they think that PAP is false, so that there can be blameworthiness without robust APs; and if OIC, together with an additional premise, implies PAP, OIC may be false as well. So, the line of argument that has taken us to deny the agent's blameworthiness is defective. According to them, some Frankfurt cases feature agents who could not act so as to get exempted from blame but are blameworthy for what they did anyway. 
At this point, a response might be to insist on the independent plausibility of OIC and on the unpalatable consequences of denying it. I think these considerations are fully correct. But it is unlikely that this line of argument can convince Frankfurt theorists. They will point to the intuitions raised by the relevant Frankfurt cases in order to reject both PAP and OIC and to show that denying the latter principle has not the unacceptable consequences one could initially expect. We would be caught in a dialectical stalemate.

\section{Doing everything one can (DEC) and Frankfurt cases}

My suggestion at this point is to resort to a new principle, drawn from common sense wisdom, which has some connections with OIC but is slightly different from it. Moreover, it is more intuitively correct than OIC. It is different because, whereas OIC relates two notions, namely moral obligation and ability or power, the new principle connects three notions, namely moral obligation, ability or power and blameworthiness. That it is more intuitive than OIC is something to be left to the reader's opinion. Let me call this principle "DEC" (from "doing everything one can"):

(DEC) If someone does everything she can reasonably do in order to fulfil her moral duties, she is not obliged to do more, and so is not morally blameworthy for not doing more. ${ }^{4}$

DEC sounds eminently correct and in full agreement with our sense of justice. It seems clearly unfair to demand from an agent to do more when she has done everything he can reasonably do in order to comply with morality. Let us now apply this principle to some examples, including Frankfurt cases.

An important feature of Frankfurt cases is that, in them, the agent believes that she can do otherwise than she in fact does, though, owing to circumstances fully

\footnotetext{
${ }^{4}$ Note that it does not follow from DEC that anyone who fails to do everything she reasonably can do to fulfil her moral duties is ipso facto morally obliged to do more and morally blameworthy for not doing it, though such a failure provides a prima facie reason for thinking that she is. I believe that this is how it should be, for otherwise DEC would often put on our shoulders too heavy moral burdens, given that in many cases we can do more, even if we do much. The qualification "reasonably" is important, as well as it is attending to the details of particular cases.
} 
unknown to her, this belief turns out to be false. A common situation with this feature might be the following:

(JOHN) In his way home from work, John meets Robert, a friend of his; Robert tells John that he urgently needs to take a taxi to get to an important meeting in time and asks him for some money, since he has realized he does not have enough cash with him; of course, he goes on, he will return the money as soon as possible. John thinks he can comply with Robert's request quite easily, but he is in rather bad temper and not in the mood to be kind; and so he responds to Robert that he is sorry but, unfortunately, he has no money with him; he forgot to take his wallet this morning while leaving home. Unknown to John, however, he actually has no money and no wallet, for a pickpocket stole it half an hour ago while John was travelling in the underground train.

Is John blameworthy for not helping Robert with the money he needed? Well, not exactly for that. If someone censured him for not helping his friend, he might reply that he is not to blame for that, since he could not have helped him. But he is not fully blameless, either. Following DEC, he did not do everything he could reasonably have done for helping his friend. He should have formed the intention to help and tried to do so by reaching for his wallet, if only to discover that it was not in his pocket. Had he done so, and given that this is everything he could reasonably have done to help his friend, he would have been entirely blameless. ${ }^{5}$ In this particular context, his attempt to help by reaching for his wallet was a fully robust, exempting alternative.

But let us change a bit the situation. Suppose that no robbery has occurred and John has in fact his wallet in his pocket. In these circumstances, reaching for his wallet would not have been enough to get rid of blame, for then there would have been something more John could have done to fulfil his duty; in the new situation, only lending the money to Robert would have made John entirely blameless. So, an act of a certain kind (John's forming the sincere intention to lend the money, manifested in his reaching for his wallet) can be an exempting alternative in a certain situation, provided

\footnotetext{
${ }^{5}$ Reasonably: John could, for example, commit a robbery to get the money Robert needed; but this would not have been a reasonable thing for him to do.
} 
that this is everything the agent could do to fulfil his obligation, but not in another, if there is something more he could have done.

A general lesson to draw might be this: in situations in which MR is at issue, the more an agent can do to fulfil her moral duties, the more she must do to get rid of blame; conversely, the less she can do, the less she must do to be blameless. So, which kinds of actions are fully robust, exempting APs is a contextual matter, and depends importantly on the effective extension, in the particular situation an agent is, of her power or ability to fulfil her moral obligations.

Now, Frankfurt cases are precisely examples of situations where an agent's powers are in fact, unbeknownst to her, severely restricted. In them, and unlike John's example, the agent cannot even form an intention or make a decision to act in a certain (morally right) way, as happens in Ann's example. Nevertheless, Frankfurt theorists insist that she is blameworthy for what she intends or decides (and does) in spite of having no robust alternative intention or decision, not to mention action, within her reach; she is blameworthy even if there is no alternative way of acting that would render her blameless. If this is correct, then PAP is false not only with respect to praise-, but to blameworthiness as well.

In the light of our preceding line of argument, however, this thesis can be challenged. Let me proceed.

Ann's example is a classical Frankfurt case. However, as a result of the discussion, cases of this sort are currently taken to be defective, though we shall not get into the reasons for this view. ${ }^{6}$ This has led Frankfurt theorists to construct new and more complex cases, which supposedly do not show the unwanted features. The following is a Frankfurt case of this new brand, which combines features of some recent Frankfurt cases: ${ }^{7}$

(MEAN): Frank is a successful businessman; he occupies a relevant position in an important company and has a pretty good financial situation. His brother Neal, instead, is in a rather precarious economic condition. One day, Neal visits Frank to tell him he has had to incur some debts, not very high indeed, but which can

\footnotetext{
${ }^{6}$ The main problem is the so-called "dilemma defence" of PAP, which has been put forward by such thinkers as Kane (1985), Widerker (1995) and Ginet (1996).

${ }^{7}$ Such as Pereboom's Tax Evasion (Pereboom 2001, 2009) or Widerker's Brain Malfunction- $W$ (Widerker 2006).
} 
cause him real trouble if he does not repay them within the next few days. So, Neal asks Frank to lend him money to cancel the debts. Frank is a rather mean and egoist person, though not pathologically so. Frank's psychology is such that, in a circumstance like this, he only could decide to lend the money to Neal if he took seriously moral reasons to do so; but taking seriously these reasons is not sufficient for him to make this decision; even if he took these reasons seriously, he still might refuse to help Neal for reasons of self-interest, related to his mean and egoist character. Unbeknownst to Frank, however, he could not even make the decision to help Neal, for his present health condition (which he is ignorant of) is such that, if he were to take seriously moral reasons to help Neal, and with them the perspective to do actually so, he would suffer a grave heart attack, with the result that he would lose consciousness and be taken to the hospital, which would make it impossible for him to lend Neal in time the money he badly needs. However, no heart attack takes place, for Frank does not take seriously moral reasons to help his poor brother and refuses to lend him the money by inventing an excuse about his own very precarious financial situation.

According to Frankfurt theorists, Frank is blameworthy for refusing to help Neal, though he could not have decided to help him. They concede that Frank had within his power taking seriously moral reasons to help Neal; this is an alternative he had, something he did not but was able to do. But this alternative, they contend, is not robust, in that it is not morally significant. It is true that, had he gone for it, he would have been exempted from blame for not helping Neal, because, by suffering a heart attack, he would have been unable to help him. But this would have happened by pure luck; Frank could not reasonably believe or foresee that, simply by taking seriously moral reasons, he would be blameless; remember that, barring Frank's present (and passing) health condition, which had no actual role in his final decision, taking such reasons seriously was fully compatible with the decision to let Neal down anyway.

With examples such as this, Frankfurt theorists seem to occupy a very solid position indeed. And we must acknowledge that MEAN (and the original cases that inspire it) is a strong example against the necessity of robust APs for blameworthiness. If thinking of moral reasons were a robust alternative, it would be very easy to get off the moral hook each time we did a morally objectionable thing, such as refusing to help a friend or a relative, as Frank did in MEAN. We might excuse ourselves in the 
following way: "Look, I have decided not to lend you the money you need, but I am not blameworthy because I have taken seriously moral reasons for lending you the money". But this is clearly ludicrous. Nobody could think of this as a valid excuse.

This is undoubtedly correct, but we can give a strong reply to it. Remember our initial example of John and Robert. We said that which ways of acting are robust, exempting APs is a contextual matter, and depends especially on what an agent can effectively do in particular circumstances. This is why if, unknown to John, he had been stolen and had no money, a sincere, though unsuccessful, intention to lend Robert the cash he needed would have exempted John from blame. But if no robbery occurred and John actually had money, the mere intention would not have been enough to exempt him from blame; only lending the money would have had this effect. By the same reasoning, if we can actually help a friend in trouble, we cannot get rid of blame for not helping him merely by taking seriously reasons for helping him. We can then explain why, in general, taking seriously moral reasons for acting in a certain morally right way is not robust enough to get rid of blame for not deciding and acting that way. But this does not mean that taking moral reasons seriously is not a moral duty in a situation like the ones we are considering. We are rightly expected to think of our friends' wellbeing and put ourselves in their shoes, as a step towards intending and doing the right thing for these right moral reasons. Failure to attend to considerations of this kind is a reason for blaming someone as selfish or inconsiderate. ${ }^{8}$

Coming back to MEAN, remember that, unknown to Frank, he could not actually help Neal; he could not even intend to help him; the only moral duty he was actually able to fulfil was precisely to think of Neal's troubles, put himself into his shoes and consider seriously reasons for helping him. So, by parity of reasoning, in the same way as, following DEC, John would have been exempted from blame by a sincere intention to help Robert if, due to the robbery, he was actually unable to help him, Frank would also have been exempted from the blame he now has for refusing to help Neal if he had taken seriously moral reasons for helping him, given that this was the only thing he could in fact have done, in the circumstances, to fulfil his moral duty to help his brother Neal. Frank did not satisfy the antecedent of the DEC principle; he did not do

\footnotetext{
${ }^{8}$ I am aware of Watson's (2004) important distinction between two aspects of responsibility; but getting thoroughly into this would take us too far away from our main line of argument. I assume that someone who is inconsiderate and refuses to help a friend in trouble is blameworthy in both aspects that Watson distinguishes.
} 
everything he could reasonably have done in order to fulfil his moral duties; he had an unfulfilled moral obligation which he could have fulfilled and did not; there is, then, reason to think that he is morally blameworthy for his refusal to help Neal. In the circumstances of the case, the tiny, though morally significant, mental act of taking moral reasons seriously was a robust, in fact exempting, alternative possibility that Frank had within his power. Therefore, MEAN and similar, highly sophisticated Frankfurt cases do not show that, in the absence of any robust, morally significant, exempting alternative, an agent can be blameworthy for what she did. Frank was blameworthy but he had such an alternative. MEAN has not shown that blameworthiness does not require APs and PAP, concerning blameworthiness, remains safe.

\section{REFERENCES}

CAPES, Justin A. (2010), “The W-defense”, Philosophical Studies 150, pp. 61-77.

DENNETT, Daniel C. (1984), Elbow Room: the varieties of free will worth wanting, Oxford, Clarendon Press.

FISCHER, John M, (1994), The Metaphysics of Free Will, Oxford, Blackwell.

FRANKFURT, Harry G. (1969), “Alternate possibilities and moral responsibility”, Journal of Philosophy 66, pp. 829-839; reprinted in (and quoted from) The Importance of What We Care About (1988), Cambridge, Cambridge University Press.

GINET, Carl (1996), "In defence of the principle of alternative possibilities: why I don't find Frankfurt's argument convincing", Philosophical Perspectives 10, pp. 403417.

KANE, Robert (1985), Free Will and Values, Albany NY, SUNY Press. 
MOYA, Carlos J. (2006), Moral Responsibility. The ways of scepticism, Abingdon and New York, Routledge.

NAYLOR, Margery B. (1984), "Frankfurt on the principle of alternate possibilities", Philosophical Studies 46, pp. 249-258.

NELKIN, Dana (2008), "Responsibility and rational abilities: defending an asymmetrical view", Pacific Philosophical Quarterly 89, pp. 497-515.

OTSUKA, Michael (1998), "Incompatibilism and the avoidability of blame", Ethics 108, pp. 685-701.

PEREBOOM, Derk (2001), Living without Free Will, Cambridge and New York, Cambridge University Press.

_ (2009), "Further thoughts about a Frankfurt-style argument", Philosophical Explorations 12, pp. 109-118.

WATSON, Gary (2004), “Two faces of responsibility”, in Agency and Answerability. Selected Essays, Oxford, Clarendon Press, pp. 260-288.

WIDERKER, David (1995), "Libertarianism and Frankfurt's attack on the principle of alternative possibilities", Philosophical Review 104, pp. 247-261.

_ (2006), "Libertarianism and the philosophical significance of Frankfurt scenarios", Journal of Philosophy 103, pp. 169-187.

WOLF, Susan (1990), Freedom within Reason, Oxford, Oxford University Press.

WYMA, Keith D. (1997), "Moral responsibility and leeway for action”, American Philosophical Quarterly 34, pp. 57-70. 